Fhiloxanthus n. g.

Agrees very closely with Cockerellia in venation and palpial characters, but is readily distinguished by the color of body which is wholly yellow, the abdomen being immaculate; the supraclypeal plate not being distinctly separated; the clypeus being semicircular at base; while the hind trochanters have a distinct flocculus; claws simple. Type Perdita beata Ckll.
Nomadopsis n. g.

Separated at once from Perdita, Cockerellia etc. by the longer marginal cell which is much longer than the stigma, fully twice as long, or as long as or longer than the first discoidal cell ; submedian cell a little shorter. than the median; maxillary palpi 4-jointed, the first joint very long, fully 7 times longer than joints 2-4 united, with a contraction at base. Type Perdita zonalis $\mathrm{Cr}$.

\title{
NEW TETTIGONINAE, WITH NOTES ON OTHERS.
}

\author{
BY C. F. BAKER, AUBURN, ALA.
}

Xerophloea major n. sp. Length $7.5 \mathrm{~mm}$., width across pronotum $2.5 \mathrm{~mm}$. Larger, more robust, and more coarsely pitted than viridis. The vertex proportionally much larger than in viridis, and broadly, evenly rounded in front, nor at all even subangulate.

Described from two females in the National Museum, collected by Mr. E. A. Schwarz in Virginia. In the National Museum there is also a specimen from the Fitch cabinet, bearing the label "Xerophloea major, Arkansas, W. S. Robertson." I have a large series of viridis Fab. from California, Colorado, Arizona, New Mexico, Texas, Kansas, Alabama, and Brazil. Major differs as above stated from anything in this series. The forms of this genus, occurring in the Northeast, should be collected in large series at many points.

Tettigonia geometrica Sign. This species is found in the United States, but has probably been confused with bifida Say, which it resembles in a most striking manner. Besides some minor details, geometrica is smaller and lacks the whitish lines on elytra. I have it from Illinois, Washington, D. C., Alabama and Louisiana.

Tettigonia circellata n. sp. Length 6-6.5 $\mathrm{mm}$. Pale yellowish, the legs and base of venter sometimes bright orange. Front usually with two longitudinal black stripes on disc, a very short one on margin next each antenna, and one transverse on clypeal suture; all these markings may be obsolete. Vertex with a black point at tip and another at center of disc; two very short transverse lines behind, their inner ends embracing the ocelli, and a large incurved line on each side near the anterior margin, arising near the tip ; these markings vary in intensity but are distinct in all the specimens. Pronotum, except anterior margin, pale blue; disc with four black spots, one on either side before the middle and one on either side behind the middle; other small dots may occur between these. Scutel yellowish, with two more or less exposed dots at base and transverse line, black. Elytra bright blue by reflected light, the apical margin transparent and the principal veins blackish; by transmitted light, the elytra appear deep smoky, with a slight bluish tinge. Wings deep smoky throughout. Prosternum, dorsum largely, and sometimes a median longitudinal row of small dots on venter, black or blue-black.

Last ventral segment of female twice length of preceding, medially raised into a strong keel, the acute point of keel termin- 
ating the sharply angled hind margin. Plates of male once and a half the length of preceding segment, narrow and slender, very gradually narrowed to tips.

Described from several males and females collected at Los Angeles, Cal., by Prof. A. P. Morse, at Prescott, Ariz., by Dr. R. E. Kunze, and one specimen in the National Museum, taken at Los Angeles by Mr. Koebele. This, one of our prettiest Tettigonids, has long borne the above Ms. name of Dr. Uhler.

Tettigonia cythura n. sp. Length $\& 5$ $\mathrm{mm}$., of $\delta 4.25 \mathrm{~mm}$. Pale yellowish, dorsum and more or less of sternum, black. Face without distinct markings. Vertex with three black dots on front edge, one at center and one on either side; on either side of the disc, near front edge and parallel with it, is a black line which originates back of the point and terminates over the frontal suture; two fine median longitudinal lines on posterior half of disc, and a small spot on either side between ocellus and eye, black. Pronotum bright green, front margin yellow, broadening laterally. Scutel with the transverse impressed line and three very fine lines connecting it with hinder margin, black, causing the whole to appear like a black double loop on basal half. Elytra bright green by reflected light (smoky by transmitted) with a bluish tinge along the claval suture and base of costal margin, the principal veins more or less darkened, the apical margin transparent. Wings deep smoky.

Last ventral segment of the female twice the length of preceding, the hind margin acutely angled, the edge emarginate on either side of the acute point. Male plates of medium length, slender, narrowing to acute, slightly diverging, dark brown points.

Described from one female and numerous males, collected at Palm Springs, Cala., by Prof. A. P. Morse. I have one specimen from Arizona, received from the Cornell University collection. This fine little species has long borne the above Ms. name of Dr. Uhler.
Tettigonia aurora n. sp. Length of $q 7$ $\mathrm{mm}$. Pale yellowish, legs inclining to orange, dorsum bright carmine. Front with three longitudinal black lines nearly throughout its length on the disc, two abbreviated dashes above, and two dots on each lateral margin, one at antennal pit, the other at clypeal angle. A transverse row of three black spots on each gena. Clypeus with a dark median line. Front edge of vertex with three black dots, one at center and one on either side. Disc of vertex with a black line on either side, near and mostly parallel with front edge, extending from a short longitudinal dash near median line and just back of apex to the frontal suture; basal half of vertex with four equidistant rectangular spots, the two outer including the ocelli, the two inner somewhat elongate. Pronotum pale, slightly tinged with reddish posteriorly, with a row of six rectangular black spots near anterior margin, and a row of four smaller ones near hind margin; disc with four indistinct longitudinal lines. Scutel yellow, with the transverse impressed line, a median longitudinal stripe, and two dots at base black. Elytra brick red, the principal veins paler, the inner apical all transparent. Wings infuscated.

Last ventral segment of female twice the length of the preceding, hind margin broadly rounded.

Described from two females collected in Arizona and received from the Cornell University collection. This is another of Dr. Uhler's Ms. species, and the three are described under these names at his request.

\section{A NEW FORM OF PULVINARIA.}

BY G. B. KING AND T. D. A. COCKERELL.

Pulvinaria innumerabilis subsp. tiliae. subsp. nov.

․ Scale $6 \mathrm{~mm}$. long, 5 broad, 2 high, varying in size, sometimes as much as $8 \mathrm{~mm}$. 

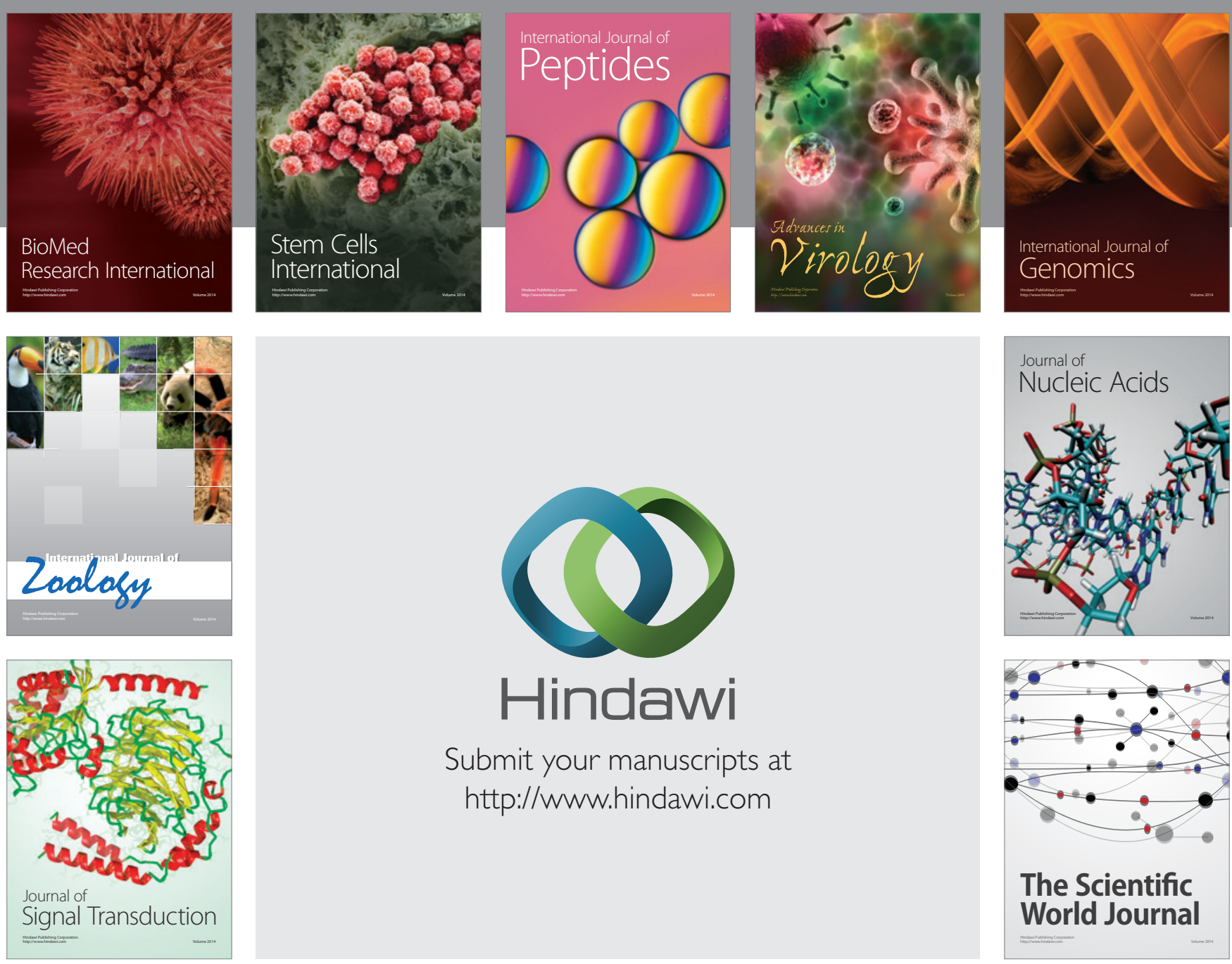

Submit your manuscripts at

http://www.hindawi.com
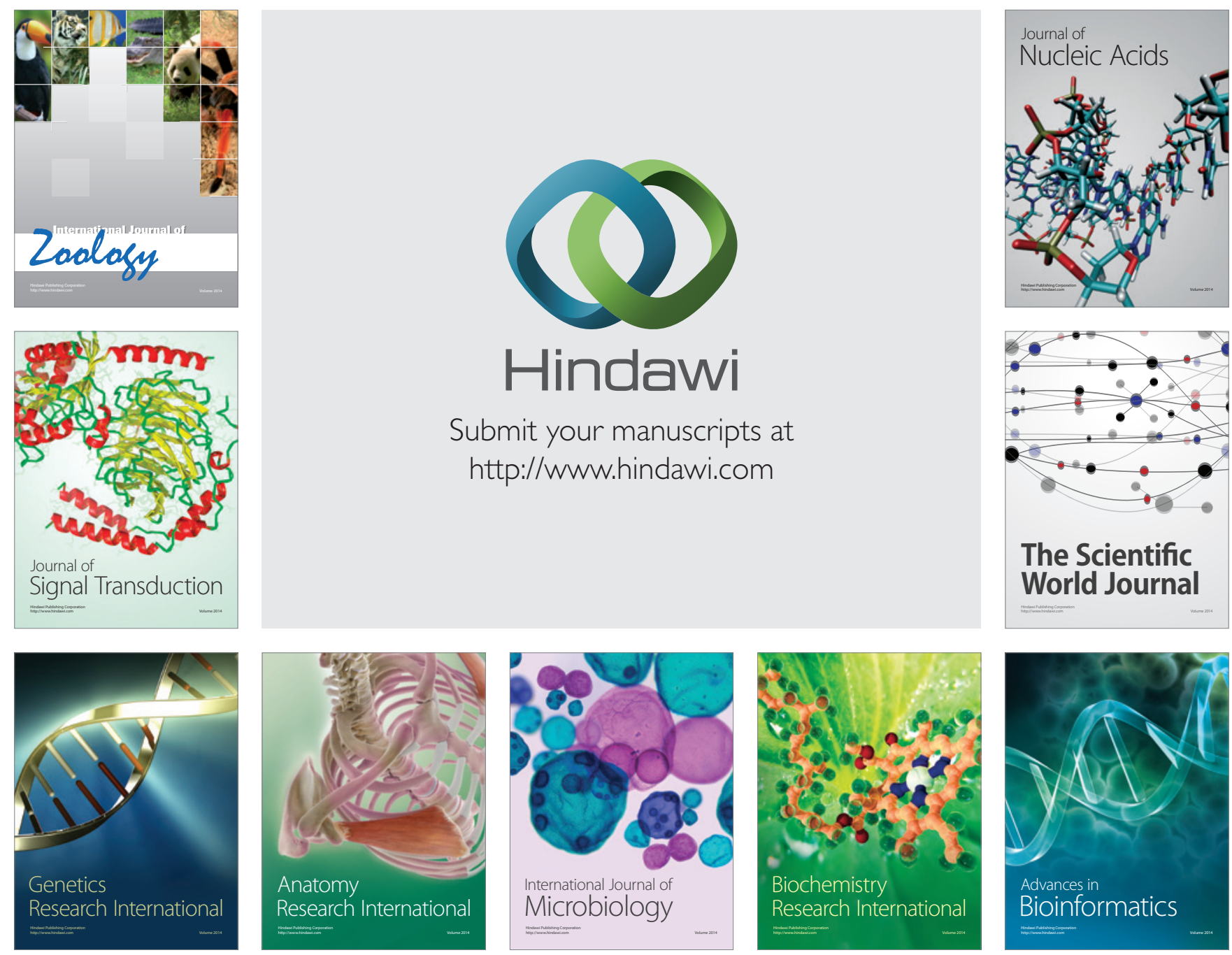

The Scientific World Journal
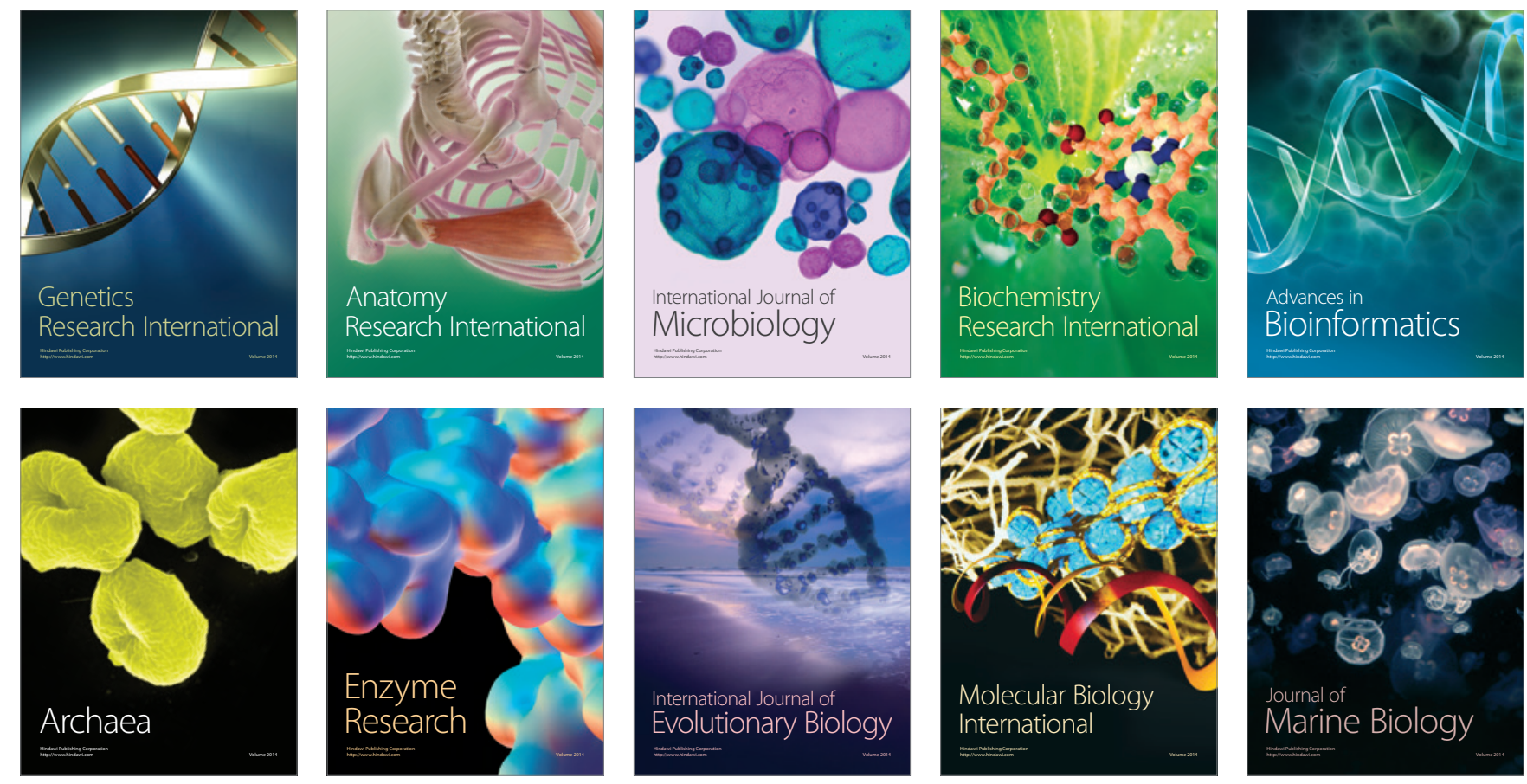